\title{
Standards of Economic Growth to Apply Creative Projects
}

\author{
Abdullah Ibrahim Nazal \\ Zarqa University, Zarqa, Jordan
}

\begin{abstract}
This study theoretically showed the importance of standards economic growth to apply creative projects to avoid loss cost and efforts. There is problem of complexity environment to understand real economic growth. Companies and government can affect economic. There is a need to make standards to control steps of economic growth as result to accounting gaps, economic gaps, and financial analysis gaps. Standards must face negative affection of speculation, government involving in economic, developing tool. Evaluating must be built up to real market price and also standards must build trust to support developing. Searcher recommended linking economic growth with real growth of producing and ways to get real market price to evaluate company assets, liabilities, and net profit after tax for all users as factors show growth in company to growth economic units which are successful by applying creative projects.
\end{abstract}

Keywords: economic growth, discloser, standards, market price, gap, producing

\section{Introduction}

There is a need to standard economic growth as result to complexity environment. Ignorance will lead to misunderstanding problem and misunderstanding the solution which costs loss of expenses, efforts, and time. In traditional case, misunderstanding causes government intervention to balance the economic with increasing of general budget expenses which may lead to deficit. Complexity environment shows that many factors affect growth and many changes of every factor. It will cause difficult to control growth planning as result to changing. Standards are way to control economic growth planning, but it needs limits to success. Many standards as accounting, financing, and economic standards face problem to give $100 \%$ correctly information. Some studies as financing analysis or economic analysis give wrong information as result to wrong data which lead to wrong planning and get in loss of time, efforts, and resources.

\section{The Problem}

There is a need to standard economic growth to apply creative project as a next step to economic developing. This step comes after total quality managing success. It deals with current needs and expects future needs and suitable way to success. Standards come because of losing disclosure in accounting, managing risks, and government effect as involving directing economic. To success creative developing, there must be standards to show real economic growth or there will be gap to lead to problem as financial crises speculation in false economic.

\footnotetext{
Abdullah Ibrahim Nazal, Ph.D., associate professor, Department of Finance and Banking, Faculty of Economics and Administrative Sciences, Zarqa University, Jordan.

Correspondence concerning this article should be addressed to Abdullah Ibrahim Nazal, P.O. Box: 132222, Zarqa 13132, Jordan.
} 


\section{The Importance}

This search helps leaders to understand problems of success in economic developing step by step. It gives standard to face losing disclosure in accounting, managing risks, and government affection as involving directing economic. It gives explanations to speculation and false data which will lead to false evaluation to economic unites and false market price. This case explains reason of loss savings, investing, and general budget expenses and leads to unsuccessful planning.

\section{The Objectives}

This search aims as follow:

(1) to explain reasons for standards to control steps of economic growth;

(2) to find standards of economic growth to apply creative developing planning.

\section{Literature Review}

Lucouw (2013) tried to solve problem of discloser. He showed the important of financial statements which must be done up to suggest model. The model recalculates certain financial statement figures to what it could have been. This can make comparing between current statements and expect statement. Heinze, Uhlmann, and Diermeier (2014) explained the importance to evaluate companies in crises because there possibility of loss evens it has good reputation. They showed that a company which faces crises can reestablish trust with shareholders by announcing an independent investigation by third party. Hassan and Abdel-Hameed (2002) showed the effect of limits tools choices and explained that financial environment affects performance of Islamic banks and Islamic bank must have big capital to achieve suitable profit. This needs obligate suitable standard to compare its capital/assets ratio rather than standards in traditional banks.

\section{Standards Reasons to Control Steps of Economic Growth}

Standards are important to control planning and adjust planning up to the results. Standards can avoid loss of disclosure case (Figure 1).

There is problem of discloser, because standards of international financial reports follow principles - based more than rules - which lead to applying the manager rules on accounting data. The important item for auditor is to estimate the fair value by discussing the manager opinion. This needs investigating from the external auditor, e.g., evaluate returns up to different ways of calculate depreciation (Atmeh \& Alzabi, 2014). Atmeh and Serdaneh (2012) explained Ijarah contract as new Islamic financing tool which needs Islamic rule standards rather than traditional standards of rent. Depreciation is provided to write the cost or valuation of tangible fixed assets by installments (Waterston, 1992). Badwin, Gellaty, Tanguay, and Partry (2005) tried to estimate depreciation rates for the productivity accounts. They used three methods to produce deprivation profiles. They analyzed estimate changes in valuation of assets over their service life, then compared among expected depreciation installment every year, and resaled the asset in market value in order to compare and made adjust to be up to asset resale value and use other methods to get depreciation rates of all assets used in the capital stock estimates. 


\section{Problem of measuring}

\begin{tabular}{|c|c|}
\hline $\begin{array}{l}\text { Accounting gaps: } \\
\text { 1. Different accounting standards give } \\
\text { different results; } \\
\text { 2. Some company operation not fixed in } \\
\text { accounting as managing risk up to future } \\
\text { expecting; } \\
\text { 3. Accounting trickery as cheating. }\end{array}$ & $\begin{array}{l}\text { Economic gaps: } \\
\text { 1. Gross domestic products is standard of growth but } \\
\text { government can increas GDP by selling land or leasing } \\
\text { land or selling products to avoid reducing of private } \\
\text { companies loss; } \\
\text { 2. Economic equilibriums are affected by speculation } \\
\text { which causes false demand and false supply. This case } \\
\text { will give false data to control gaps of producing to } \\
\text { cover real need and get false result to expect returns. }\end{array}$ \\
\hline \multicolumn{2}{|c|}{$\begin{array}{l}\text { Financial analysis gaps: } \\
\text { 1. Experience is not enough; } \\
\text { 2. Fast changing of affect factors limit time of accepts analysis results; } \\
\text { 3. Financial tables had been given to analyst from the company with limit explanation; } \\
\text { 4. It depends on accounting data and economic data which have problem; } \\
\text { 5. Managing risks affection is not clear. }\end{array}$} \\
\hline
\end{tabular}

Figure 1. Economic growth problem of measuring.

\section{Economic Growth Standards}

This search found that creative project is a way to develop economic after success of total quality managing, but it needs standards to success. Standards are related to companies as unit of economic and standards of country producing returns as index. Standards face gabs of real data as a result of loss disclosure. This happens by company accounting documentary, transfer risk, speculation, and financial analysis reports. Government may cause gaps as a result of involving in market as ruler, general budget expenses, government companies producing, and government speculations. It leads to complexity to understand real economic growth. Companies and government can affect standards of economic as a result of giving false return by trickery or by control factors affect on standards. This case can keep its credit classification in good type in spite of real loss of growth.

In some countries, creative developing causes loss as a result of loss experts, while other countries succeed in long term. Some economics get in speculation on creative developing projects to get increasing shares price in market up to expecting success which will make unusual returns. This case may get in gap as a result of unsuccessful projects and cause unusual loss in markets. It is important to standard economic operations and company operations up to needs as follow:

(1) Standards to face negative affect of speculation. Speculation is done by individuals, companies, and government in some countries. Share market gives share value automatically and continuously provided for both by management and investors (Lumpy \& Jones, 2001). This rule needs to be discussed as a result of differences between a growth company as strategy and its growth share price. Eun, Resnick, and Sabherwal (2012, p. 276) said that "market capitalization of a most national equity markets in developed countries 
declined from 2005 to 2009 as a result of global financial crisis". Company assets may become speculation assets. This case will lead to company success by speculation success. It causes ignorance of real company growth and affects economic. Selling shares mean problem in company managing. Chatterji, Levine, and Toffel (2009) found that poor social responsibility leads to sell-outs of companies' shares which decrease companies' financial performance.

Gap of shares value can be faced by revaluating value of assets, liabilities up to real price in the market beside company net profit after tax. It can be measures of growth. Growing means increase of assets and increase of net profit after tax and it also calculates reduce of liabilities value as growth.

(2) Standards of government involving in economic. Seal and Ball (2011) explained that general budget management is affected by structural changing in the economic sector and time of needs. Budget strategy and its items adjustment are also affected. Financing general budget by deficit becomes problem in case there is decreasing of gross domestic producing (Makin, 2002). Government involving will affect economic equilibrium, e.g., government increase tax to reduce deficient. Some companies face problem of increasing tax by clear company and going to other country which reduces local supply. There is a role for government involvement in economy, because of bad affect on market system automatically functions (Van Den Berg, 2001).

Gaps of bad affection on economic growth by government must be discussed with the affection and comparing with other ways as developing tools, e.g., sharing in investing by companies and government.

(3) Standards of evaluation companies, individuals, and government savings and investing. Standards must be clear and fixed to give the real case. Standards of disclosure can be faced by getting real data from accounting department also evaluate the assets, liabilities, and return after tax by real market pricing. There is a need to add evaluation standards among companies, dealers, and government to measure success with human resource, customers, suppliers, creditors, shareholders, and government satisfied.

(4) Standards of building trust. Heinze et al. (2014) showed that a company which faces crises can reestablish trust with shareholders by announcing an independent investigation by third party. Trust comes as result of trusting the third party. The important to evaluate companies in crises was explained, because there a possibility of loss evens that it has good reputation. Third party could be the government or financial analysis or any authorized organization.

(5) Standards to face negative affection of developing tools. Developing tools may restructure company organization and restructure economic producing. "There is a strong statistical relationship between product development and economic development. This is often presented as evidence that product development causes economic development by promoting investment and making allocation of resources more efficient" (Amaral \& Quintin, 2010, p. 804). Thomas (2011) explained that the standard of success tools types is to finance and invest up to suitable time with suitable cost, so there must be financing tool, investment tools, and saving tools to make money staying. Tools have been developed to help government, companies, and individuals. Its types developed as result of managing risk. It helps to reduce loss, to get commission, and to transfer loss to other dealers. The ways of risk managing may cause to restructure managing of organizing and financing or investing restructuring in indirect way. Expecting always depend on factors. Managing risk will change these factors, therefore it will change result of economic unities and also affect economic growth as a result of current loss and expecting loss affections (Figure 2). 
Managing risks (managing investing and financing risks)

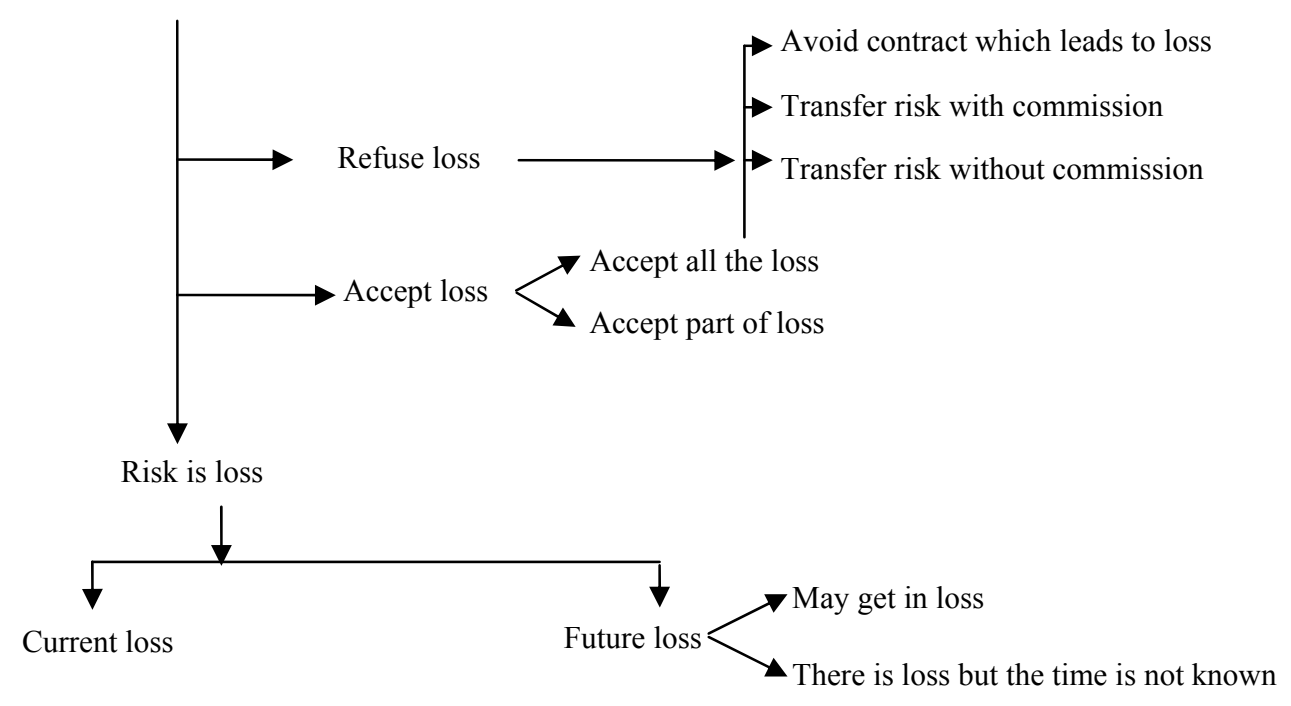

Figure 2. Managing risks.

Ways of managing risks cause changing which affects accounting data, financial analysis report, and economic data do not show the real effect in correctly number $100 \%$. There is a gap as result of fast dealing in managing risk than documentary operations, therefore there is misunderstanding of real economic growth. Mengle, Kuprianov, and Pachos (2009, p. 217) said that "in 2009, there were 94\% of the world's largest corporations report using derivatives to manage business and macroeconomic risks". Practically, derivatives are promising to cover demand. Problem comes as a result to make change of equilibrium point between demand and supply because false demand causes false supply to producer. Derivatives speculation becomes gambling tool not hedge risk tool.

Derivatives are complex and involve risks of several kinds. Both theoretical and practical methods deal with risk by mathematics sophistication by building and formulating a mathematical model which includes clauses to identified factors (Bielecki \& Rutkowski, 2002).

Success of any developed tool has limits, e.g., Clemons and Hitt (2000) explained that Internet services show different way of pricing. Internet reduces cost of transfer and increases customer surplus which courage customer to make addition investment in Internet bank service. Kheng, Mahamad, Ramayah, and Mosahab (2010) found that electronic services quality was affected by changing role of the banking system and dynamic financial market. They are responsible to customer loyalty.

\section{Conclusions}

This search found that creative project is a way to develop economic after success of total quality managing, but it needs standards to success. Conclusions are drawn as follows:

(1) Standards are related to companies as a unit of economic and standards of country producing returns as index. Standards face gabs of real data as a result of loss disclosure. This happens by company accounting documentary, transfer risk, speculation, and financial analysis reports. Government may cause gaps as a result 
of involving in market as ruler, general budget expenses, government companies producing, and government speculations. It leads to complexity to understand real economic growth.

(2) Companies and government can affect standards of economic as a result to give false return by trickery or by control factors affect on standards. This case can keep its credit classification in good type in spite of real loss of growth.

\section{Recommendation}

Searcher recommended linking economic growth with real growth of producing and also ways to get real market price to evaluate company assets, liabilities, and net profit after tax for all users as factors show growth in company to growth economic units.

\section{References}

Amaral, P. S., \& Quintin, E. (2010). Limited enforcement, financial intermediation, and economic development: A quantitative assessment. International Economic Review, 51(3), 785-811.

Atmeh, M. A., \& Serdaneh, J. A. (2012). A proposed mode for accounting treatment of Ijarah. International Journal of Business and Management, 7(18), 51-53.

Atmeh, M., \& Alzabi, Z. (2014). The role of the audit profession in strengthening oversight and anti-corruption. Proceedings from Tenth International Scientific Conference Professional, Amman, Jordan.

Badwin, J., Gellaty, G., Tanguay, M., \& Partry, A. (2005). Estimating depreciation rates for the productivity accounts. Retrieved from http://www.oecd.org/std/productivity-stats/35409605.pdf

Bielecki, T. R., \& Rutkowski, M. (2002). Credit risk: Modeling, valuation, and hedging. New York: Springer Finance.

Chatterji, A. K., Levine, D. I., \& Toffel, M. W. (2009). How well do social ratings actually measure corporate social responsibility? Retrieved from http://www.hbs.edu/faculty/Publication\%20Files/07-051.pdf

Clemons, E. K., \& Hitt, L. M. (2000). The internet and the future of financial services: Transparency, differential pricing and disintermediation. Retrieved from http://fic.wharton.upenn.edu/fic/papers/00/0035.pdf

Eun, C. S., Resnick, B. G., \& Sabherwal, S. (2012). International finance (6th ed.). New York: McGraw-Hill Companies Publisher.

Hassan, M. K., \& Abdel-Hameed, M. B. (2002). Determinants of Islamic banking profitability (ERF Pape). Retrieved from http://www.kantakji.com/media/3016/kabir_bashir.pdf

Heinze, J., Uhlmann, E. L., \& Diermeier, D. (2014). Unlikely allies: Credibility transfer during corporate crisis. Journal of Applied Social Psychology, 44(5), 392-397.

Kheng, L. L., Mahamad, O., Ramayah, T., \& Mosahab, R. (2010). The impact of service quality on customer loyalty: A study of bank in Penang, Malaysia. International Journal of Marketing Studies, 2(2), 57.

Lucouw, L. (2013). Interpreting financial statements. Journal of Finance and Investment Analysis, 2(1), 69-71.

Lumpy, S., \& Jones, C. (2001). Investment appraisal and financial decisions (6th ed.). London: Thomson Learning Publisher.

Makin, A. J. (2002). International macroeconomics. London: Pearson Education Limited.

Mengle, D., Kuprianov, A., \& Pachos, J. (2009). Derivatives usage survey: OTC derivatives in Russia. New York: Julia Pachos Publisher.

Seal, W., \& Ball, A. (2011). Interpreting the dynamics of public sector budgeting: A dialectic of control approach. Financial Accountability \& Management, 27(4), 409-436.

Thomas, H. W. Z. (2011). Saving finance emigration and worker remittances serve to make staying rather than migrating possible. International Economic Journal, 25(3), 373.

Van den Berg, H. (2001). Economic growth and development-An analysis of our greatest economic achievements and our most exciting challenges. Boston, Mass.: McGraw-Hill.

Waterston, C. (1992). Introduction to financial accounting (3rd ed.). London: Rutledge. 